
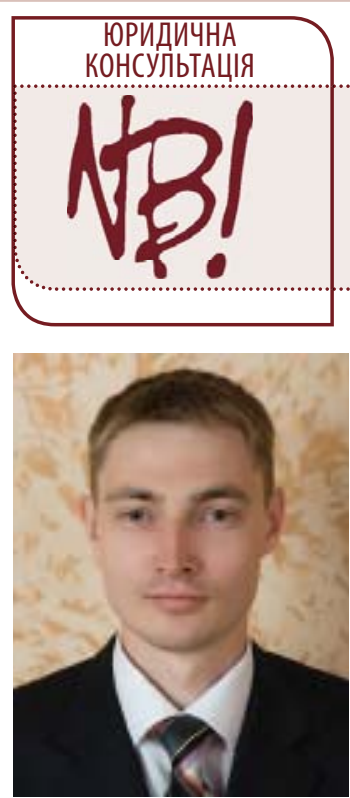

K.M. KOCTIH

адвокат, адвокатське об'єднання «Юридичне об'єднання «Феміда», член Громадської спілки «Українська асоціація медичного туризму»

Цією публікацією ми починаємо нову рубрику нашого журналу: «Юристи - лікарям». Вона стане в нагоді тим, кого цікавить правова сторона відносин лікарів та пацієнтів, лікарів та страхових та фармацевтичних компаній. Свої запитання щодо юридичного забезпечення у галузі надання медичних послуг надсилайте на адресу editor_re@ukr.net

\section{Чи можуть негромадяни України стати батьками дитини за допомогою сурогатної матері в Україні?}

Україна $\epsilon$ однією з небагатьох країн світу, в якій на законодавчому рівні закріплена можливість стати батьками за допомогою сурогатного материнства.

Так, Україною в 2013 році був затверджений Порядок застосування допоміжних репродуктивних технологій в Україні, який регулює відносини між пацієнтами (жінками, чоловіками) та закладами охорони здоров'я, які забезпечують застосування методик допоміжних репродуктивних технологій, визначає механізм та умови застосування методик допоміжних репродуктивних технологій, у тому числі, визначений порядок державної реєстрації факту народження дитини, запис про батьків дитини та перелік документів як зі сторони сурогатної матері, так і подружжя, необхідний для проведення сурогатного материнства.

Статтею 123 Сімейного кодексу України передбачено, що у разі народження дружиною дитини, зачатої в результаті застосування допоміжних репродуктивних технологій, здійснених за письмовою згодою іiї чоловіка, він записується батьком дитини. У разі перенесення в організм іншої жінки ембріона людини, зачатого подружжям (чоловіком та жінкою) в результаті застосування допоміжних репродуктивних технологій, батьками дитини $\epsilon$ подружжя. Подружжя визнається батьками дитини, народженої дружиною після перенесення в її організм ембріона людини, зачатого ії чоловіком та іншою жінкою в результаті застосування допоміжних репродуктивних технологій.

Отже, зазначеними нормативними актами Україна визначила основні питання сурогатного материнства та в подальшому робить усе, щоб вдосконалити та ліквідувати прогалини в законодавстві, яке регулює сурогатне материнство. Відтак до Верховної Ради України внесений на розгляд проект Закону України «Про репродуктивні права та гарантії їх здійснення».

Але $\epsilon$ країни, в яких сурогатне материнство заборонене, зокрема це Німеччина, Італія, Франція, Бельгія, Люксембург, Нідерланди, Данія, Польща, Угорщина, деякі штати США та ін. Підстави різні морально-етичні, релігійні та власний негативний досвід, який змусив відмовитись від сурогатного материнства.

Чи можуть громадяни цих країн стати батьками дитини за допомогою сурогатної матері в Україні? Потрібно звернутися до Конституції України, в якій закріплено, що іноземці та особи без громадянства, що перебувають в Україні на законних підставах, користуються тими самими правами і свободами, а також несуть такі самі обов'язки, як і громадяни України.

Таким чином, іноземні громадяни на рівні з громадянами України мають можливість стати батьками за допомогою сурогатного материнства, провівши відповідні медичні процедури та уклавши нотаріальних договір із майбутньою сурогатною матір'ю.

Знайти сурогатну матір можна, звернувшись до клінік, які спеціалізуються в даній галузі медицини, в яких $\epsilon$ так званий банк сурогатних мам. Фахівці радять звертатися саме до таких клінік, адже вони дають гарантію на те, що їхні «мами» протягом вагітності не палитимуть та не вживатимуть спиртні напої, всі вони здорові, одружені та мають своїх дітей. Лікарі-психологи говорять, що «наявність своїх дітей у сурогатної матері $€$ важливим у цій справі, виникнення материнського почуття зводиться до мінімуму».

\section{Які проблеми можуть постати перед іноземцями?}

Перш за все, відмова сурогатної матері надати письмову згоду про запис батьками дитини біологічних батьків, іншими словами відмова віддати дитину біологічним батькам. Сурогатна мати може піти на це через материнські почуття, неналежне виконання договору зі сторони біологічних батьків, шантаж зробити аборт, щоб отримати додаткові гроші та іншу вигоду.

Захиститися можна за допомогою договору між сурогатною матір'ю та біологічними батьками, в якому передбачити всі можливі в майбутньому проблемні ситуації та зробити все можливе для уникнення їх або встановити порядок їх вирішення, передбачити гарантії всіх учасників сурогатного материнства, особливості та розмір грошової винагороди, відповідальність сурогатної матері в разі відмови віддати дитину (повернення біологічним батькам усіх понесених ними фактичних витрат та/або штраф) тощо.

Раджу підписувати договори між клініками, які, в свою чергу, підписують договір із сурогатною матір'ю, - це максимально захистить інтереси біологічних батьків. Клініки зацікавлені в успішному вирішенні питання, а негативний відгук може відлякувати потенційних клієнтів. Але важливо пам'ятати, що договір між сурогатною матір'ю та біологічними батьками підписати потрібно обов'язково, відповідно до законодавства, без нього неможливе проведення сурогатного материнства.

Треба зазначити, що після реєстрації народження дитини, в якому потрібно зазначити, що біологічні батьки $\epsilon$ батьками дитини, сурогатна мати не має права звернутися до суду про оспорювання материнства біологічною матір'ю, про це наголошує стаття 139 Сімейного кодексу України.

По-друге, проблема може виникнути під час ввезення дитини до країни походження іноземців, в країнах Європи дитина, народжена від сурогатної матері з інших країн, не має право на громадянство.

Все ж таки, безвихідних ситуацій немає. Вихід знайшов німецький адвокат. Він зазначив, що «необхідно підтвердити батьківство генетичного тата, в свою чергу, сурогатна матір з України дає дозвіл на виїзд дитини до батька в Німеччину, і вже там його усиновлює біологічна мати. За німецьким законодавством, законним батьком визнається генетичний тато».

Підсумовуючи, відзначу, що в Україні $\epsilon$ законодавство, яке регулює питання сурогатного материнства та немає заборон щодо біологічних батьків-іноземців, а з усіх складних ситуацій можна знайти вихід, головне - підійти до цього у супроводі фахівців. 